\title{
Neem (Azadirachta Indica L.) and Oocyte Quality
}

\author{
Meenakshi Tiwari ${ }^{1}$, Anumegha Gupta ${ }^{1}$, Shilpa Prasad ${ }^{1}$, Anima Tripathi ${ }^{1}$, Pramod K Yadav ${ }^{1}$, Ashutosh N Pandey ${ }^{1}$, \\ Karuppanan V Premkumar' ${ }^{1}$, Ajai K Pandey², Tulsidas G Shrivastav ${ }^{3}$ and Shail K Chaube ${ }^{1 *}$
}

${ }^{1}$ Department of Zoology, Institute of Science, Banaras Hindu University, India

${ }^{2}$ Department of Kayachkitsa, Faculty of Ayurveda, Banaras Hindu University, India

${ }^{3}$ Department of Reproductive Biomedicine, National Institute of Health and Family Welfare, India

Submission: March 21, 2017; Published: April 19, 2017

*Corresponding author: Shail K Chaube, Cell Physiology Laboratory, Department of Zoology, Institute of Science, Banaras Hindu University, Varanasi-221005, India, Fax: 091-542-2368174, Tel: 091-542-6702516; Email: shailchaubey@gmail.com

\begin{abstract}
Neem (Azadirachta indica L.) leaf has been used as a birth control in traditional as well as ayurvedic systems of medicine for a long time. The molecular mechanism by which neem bioactive ingredients regulate female fertility remains poorly understood. Studies carried out on experimental mammals suggest that neem leaf extract induces generation of reactive oxygen species (ROS) in ovarian follicles. The increased ROS level induces granulosa cell apoptosis through mitochondria-mediated pathway. Premature death of encircling granulosa cells directly affect the achievement of meiotic competence and thereby oocyte quality after ovulation. In addition, the increased levels of ROS enter in the follicular oocytes and deteriorate its quality by inducing mitochondria-mediated apoptosis. The granulosa cells as well as oocyte apoptosis within the follicular microenvironment deteriorate oocyte quality. Poor quality directly affects fertilization, implantation and pregnancy rates and increases abortion rate. Thus, based on existing animal as well as human studies, we are in opinion that bioactive ingredients of neem particularly neem leaf extract could be used as reversible herbal female contraceptive during fertility management in human.
\end{abstract}

Keywords: Aqueous neem leaf extract; Reactive oxygen species; Granulosa cell; Oocyte; Apoptosis; Fertility management

Abbreviations: GV: Germinal Vesicle; M-II: Metaphase-II; ROS: Reactive Oxygen Species

\section{Introduction}

Mammalian ovary is a dynamic organ that is responsible for the production of competent oocytes required for successful fertilization and early embryonic development [1,2]. The meiotic competency folliocular is achieved within the follicular environment during final stages of folliculogenesis [3-7]. The achievement of meiotic competency starts in diplotene arrested oocytes, possessing germinal vesicle (GV) as well as nucleolus [1,5,8-12]. The diplotene arrest for such a long period is due to transfer of several molecules from encircling granulosa cells to the oocyte [1,6-8]. Pituitary gonadotropin(s) surge disrupt gap junction as well as cumulus-oocyte communication thereby transfer of meiosis inhibitory factors [13-15]. The interruption in the transfer of inhibitory molecules results in meiotic resumption of follicular oocytes in vivo in the presence of pituitary gonadotropin(s). The spontaneous resumption of meiosis can be achieved if cumulus-oocyte complexes are removed from ovarian follicles and cultured in appropriate medium for extended period of time [1,6-8]. Meiotic resumption from diplotene arrest occurs due to interruption in the transfer of inhibitory factors from surrounding granulosa cells to the oocytes under in vitro conditions [13-15]. Although meiosis resumes due to physical removal of encircling granulosa cells, oocyte becomes more susceptible towards in vitro culture conditions mediated apoptosis [16-20]. This is supported by observations that GV stage (immature) oocytes are more susceptible towards oxidative stress-mediated apoptosis as compared to metaphaseII (M-II) stage (mature) oocytes [9,10,16-20]. The achievement of meiotic competency not only produces a right female gamete but also enhances its ability to resist any adverse changes under in vitro culture conditions during various assisted reproductive technology programs.

Achievement of meiotic competency in follicular oocytes starts with resumption from diplotene arrest [8] and ends with the achievement of M-II stage by extruding first polar body in most of the mammalian species [5,6,11,12,21-26]. The successful completion of meiotic competency is prerequisite for the determination of oocyte quality post ovulation. Several factors that are either released from encircling granulosa cells or 


\section{Global Journal of Reproductive Medicine}

from oocyte itself regulate oocyte quality $[3,6,7,20,23,26]$. Thus, achievement of meiotic competency can easily be targeted to deteriorate oocyte quality post ovulation.

Oocyte is one of the most important factors that directly affect reproductive health of a female. Unfortunately, oocyte has not been targeted for the development of female contraceptives. Today, several drugs are available as female contraceptives but they are steroid based and they do not have $100 \%$ efficacy. Due to several side effects, these drugs are not easily accepted by reproductively active females. Hence, it is important to search herbal-based reversible contraceptives that are easily acceptable and show minimal side effects with $100 \%$ efficacy.

Neem plant (Azadirachta indica L.) is the most important medicinal plant globally. The utilities of this plant are listed in 'Charak-Samhita' and 'Susruta-Samhita' that are foundation of Indian system of natural treatment, ayurveda [27]. Various parts of neem plant are used for treatment of several diseases in traditional as well as ayurvedic systems of medicine globally. The aqueous extract of neem bark has been used to control gastric hypersecretion and gastroduodenal ulcer [28] and leaf extract is used to reduce oral infection and plaque index [29,30].

Neem leaf extract has anti-inflammatory, immunomodulatory, anti-ulcer, anti-hyperglycemic, antiviral, anti-bacterial, antifungal, nematicidal, anti-malarial, insecticidal, anti-oxidant and anti-mutagenic properties [31-36]. The apoptosis inducing ability of neem leaf extract has been investigated in cancer cells $[37,38]$. The neem leaf extract induces cytoplasmic granulation and deteriorates oocyte quality suggesting its potential use for female fertility regulation [39]. The anti-fertility properties of neem extracts have been reported in several mammalian species $[34,40]$.

The neem leaves have been used to avoid pregnancy and as birth control in traditional system of Indian medicine [41-43]. However, the possible mechanism by which bioactive ingredients of neem control fertility remains to be elucidated. Few studies suggest that neem oil inhibits follicular development in rat and induces degeneration of oocyte $[44,45]$. Further, neem oil inhibits implantation in rats and bonnet monkeys and acts as a reversible contraceptive $[42,46]$. Neem oil has been used as vaginal herbal contraceptive in human [47]. However, due to unpleasant sharp odour, neem oil is not easily palatable. The aqueous neem leaf extract does not possess an unpleasant characteristic sharp odour of neem. Hence, it could be used as an alternative herbal medicine for fertility regulation in mammals including human [41].

The mechanism by which neem leaf extract acts at the level of ovarian follicles remains unclear. Studies using experimental mammals suggest that neem leaf extract inhibits folliculogenesis and antrum formation in follicles $[40,44,45]$. The neem leaves extract triggers apoptosis in granulosa cells, reduces number of granulosa cells encircling oocyte and induces oocyte apoptosis in majority of ovulated cumulus oocytes complexes $[17,18]$. The aqueous neem leaf extract decrease catalase activity and increases ROS level in rat ovary [10,16-18]. The increased levels of ROS induce overexpression of p53 and Bax proteins. The increased Bax expression modulates mitochondrial membrane potential and induces cytochrome $\mathrm{c}$ release. Increased cytochrome c concentration induces DNA fragmentation and granulosa cell apoptosis $[6,7,10,16-20]$.

The granulosa cell apoptosis leads to disruption of gap junctions between encircling somatic cells and oocyte within the follicle. Reduced intercellular communication deprives oocyte from nutrients, maturation-enabling factors, survival factors and induces susceptibility towards apoptosis [10,18-20]. The granulosa cell apoptosis reduces estradiol 17- $\beta$ level required for development and maturation of oocytes in the ovary during final stages of folliculo genesis. The hypo-estrogenic condition may affect development and maturation of oocytes and trigger apoptosis. Studies from our laboratory suggest that quercetin induces cell shrinkage, membrane leakage, cytoplasmic granulation and cytoplasmic fragmentation in rat oocytes. These morphological apoptotic changes are associated with increased ROS level, overexpression of Bax protein, caspase-3 activation and DNA fragmentation [10,16-18].

\section{Conclusion}

Based on the existing information, we propose that neem leaf extract and its bioactive ingredients induce ROS-mediated granulosa cell apoptosis followed by oocyte apoptosis. The neem leaf extract-induced oocyte apoptosis deteriorates oocyte quality that reduces reproductive outcome. The apoptosis inducing property of neem leaf extract makes it a potential candidate for the development of reversible herbal contraceptive.

\section{Acknowledgement}

Authorsare thankfulto Department of Science and Technology, New Delhi, India, for financial assistance (EMR/2014/000702).

\section{References}

1. Mehlmann LM (2005) Stops and starts in mammalian oocytes: Recent advances in understanding the regulation of meiotic arrest and oocyte maturation. Reproduction 130(6): 791-799.

2. Barrett SL, Albertini DF (2010) Cumulus cell contact during oocyte maturation in mice regulates meiotic spindle positioning and enhances developmental competence. J Assist Reprod Genet 27(1): 29-39.

3. Albertini DF (2011) A cell for every season: the ovarian granulosa cell. J Assist Reprod Genet 28(10): 877-878.

4. Li R, Albertini DF (2013) The road to maturation: somatic cell interaction and self-organization of the mammalian oocyte. Nat Rev Mol Cell Biol 14(3): 141-152.

5. Tripathi A, Kumar KV, Chaube SK (2010) Meiotic cell cycle arrest in mammalian oocytes. J Cell Physiol 223(3): 592-600.

6. Tiwari M, Prasad S, Tripathi A, Pandey AN, Singh AK, et al. (2016) Involvement of reactive oxygen species in meiotic cell cycle regulation and apoptosis in mammalian oocytes. Reactive Oxygen Species 1(2): 110-116. 


\section{Global Journal of Reproductive Medicine}

7. Tiwari M, Prasad S, Shrivastav TG, Chaube SK (2017) Calcium signaling during meiotic cell cycle regulation and apoptosis in mammalian oocytes. J Cell Physiol 232(5): 976-981.

8. Pandey AN, Tripathi A, Premkumar KV, Shrivastav TG, Chaube SK (2010) Reactive Oxygen and Nitrogen species during meiotic resumption from diplotene arrest in Mammalian Oocytes. J Cell Biochem 111(3): 521528.

9. Chaube SK, Shrivastav TG, Prasad S, Tiwari M, Tripathi A, et al. (2014) Clomiphene citrate induces ROS-mediated apoptosis in mammalian oocytes. Open J Apoptosis 3: 52-58.

10. Chaube SK, Shrivastav TG, Tiwari M, Prasad S, Tripathi A, et al. (2014) Neem (Azadirachta indica L.) leaf extract deteriorates oocyte quality by inducing ROS-mediated apoptosis in mammals. Springer Plus 3: 464.

11. Chaube SK, Prasad S, Tiwari M (2016) Abortive spontaneous egg activation a limiting factor for reproductive outcome in mammals. RRJZS 4(2): 1-2.

12. Chaube SK, Prasad S, Tiwari M, Gupta A (2016) Rat: An interesting model to study oocyte meiosis in mammals. RRJZS 4(3): 25-27.

13. Russell DL, Gilchrist RB, Brown HM, Thompson JG (2016) Bidirectional communication between cumulus cells and the oocyte: old hands and new players? Theriogenology 86(1): 62-68.

14. Tiwari M, Chaube SK (2016) Moderate increase of reactive oxygen species triggers meiotic resumption in rat follicular oocytes. J Obstet Gynaecol Res 42(5): 536-546.

15. Gupta A, Tiwari M, Prasad S, Chaube SK (2017) Role of cyclic nucleotide phosphodiesterases during meiotic resumption from diplotene arrest in mammalian oocytes. J Cell Biochem 180(3): 446-452.

16. Chaube SK, Prasad PV, Khillare B, Shrivastav TG (2006) Extract of Azadirachta indica (Neem) leaf induces apoptosis in rat oocytes cultured in vitro. Fertil Steril 85(Suppl 1): 1223-1231.

17. Tripathi A, Shrivastav TG, Chaube SK (2012) Aqueous extract of Azadirachta indica (neem) leaf induces generation of reactive oxygen species and mitochondria-mediated apoptosis in rat oocytes. J Assist Reprod Genet 29(1): 15-23.

18. Tripathi A, Shrivastav TG, Chaube SK (2013) An increase of granulosa cell apoptosis mediates aqueous neem (Azadirachta indica) leaf extract induced oocyte apoptosis in rat. Int J Appl Basic Med Res 3(1): 27-36.

19. Tiwari M, Prasad S, Tripathi A, Pandey AN, Ali I, et al. (2015) Apoptosis in mammalian oocytes: A review. Apoptosis 20 (8): 1019-1025.

20. Tiwari M, Tripathi A, Chaube SK (2017) Presence of encircling granulosa cells protects against oxidative stress-induced apoptosis in rat eggs cultured in vitro. Apoptosis 22(1): 98-107.

21. Chebotareva T, Taylor J, Mullins JJ, Wilmut I (2011) Rat eggs cannot wait: Spontaneous exit from meiotic metaphase-II arrest. Mol Reprod Dev 78(10-11): 795-807.

22. Prasad S, Tiwari M, Koch B, Chaube SK (2015) Morphological, cellular and molecular changes during postovulatory aging in mammals. J Biomed Sci 22: 36.

23. Prasad S, Tiwari M, Tripathi A, Pandey AN, Chaube SK (2015) Changes in signal molecules and maturation promoting factor levels associate with spontaneous resumption of meiosis in rat oocytes. Cell Biol Int 39(6): 759-769.

24. Prasad S, Tiwari M, Pandey AN, Shrivastav TG, Chaube SK (2016) Impact of stress on oocyte quality and reproductive outcome. J Biomed Sci 23: 36

25. Prasad S, Tiwari M, Chaube SK (2017) Abortive spontaneous egg activation: an emerging biological threat for the existence of mammals. Cell Reprogram 19(3) (in press).
26. Tiwari M, Prasad S, Pandey AN, Premkumar KV, Tripathi A, et al. (2017) Nitric oxide signaling during meiotic cell cycle regulation in mammalian oocytes. Front BioSci S9: 307-318.

27. Girish K, Shankara Bhat S (2008) Neem- A Green Treasure. e J Biol 4(3): 102-111.

28. Bandyopadhyay U, Biswas K, Sengupta A, Moitra P, Dutta P, et al. (2004) Clinical studies on the effect of neem (Azadirachta indica) bark extract on gastric secretion and gastroduodenal ulcer. Life Sci 75(24): 28672878.

29. Pai MR, Acharya LD, Udupa N (2004) Evaluation of antiplaque activity of Azadirachta indica leaf extract gel-a 6-week clinical study. J Ethanopharmacol 90(1): 99-103.

30. Pai MR, Acharya LD, Udupa N (2004) The effect of two different dental gels and a mouthwash on plaque and gingival scores: a 6-week clinical study. Int Dent J 54(4): 219-223.

31. Sharma V, Walia S, Kumar J, Nair MG, Parmar BS (2003) An efficient method for the purification and characterization of nematicidal azadirectins A, B, and H, using MPLC and ESIMS. J Agric Food Chem 51(14): 3966-3972.

32. Udeinya IJ, Mbah AU, Chijioke CP, Shu EN (2004) An antimalarial extract from neem leaves is antiretroviral. Trans R Soc Trop Med Hyg 98(7): 435-437.

33. Siddiqui BS, Rasheed M, Ilyas F, Gulzar T, Tariq RM, et al. (2004) Analysis of insecticidal Azadirachta indica. A. Juss. fractions. Z Naturforsch C 59(1-2): 104-112.

34. Subapriya R, Nagini S (2005) Medicinal properties of neem leaves: a review. Curr Med Chem AntiCancer Agents 5(2): 149-156.

35. Sithisarn P, Gritsanapan W (2008) Variability of antioxidative quercetin content in Siamese neem tree leaves in Thailand by TLC densitometry. Acta Hort (ISHS) 786: 61-66.

36. Auta T, Hassan AT (2016) Alteration in oestrus cycle and implantation in Mus musculus administered aqueous wood ash extract of Azadirachta indica (neem). Asian Pacific J Reprod 5(3): 188-192.

37. Harish Kumar G, Priyadarsini RV, Vinothini G, Vidjaya LP, Nagini $S$ (2010) The neem limonoids azadirachtin and nimbolide inhibit cell proliferation and induce apoptosis in an animal model of oral oncogenesis. Invest New Drugs 28(4): 392-401.

38. Dharmalingam N, Gunadharini PE, Ramachandran A, Kalimuthu S, Jagadeesan A (2011) Induction of apoptosis and inhibition of PI3K/Akt pathway in PC-3 and LNCaP prostate cancer cells by ethanolic neem leaf extract. J Ethanopharmacol 134(3): 644-650.

39. Denardi SE, Bechara GH, Oliveira PR, Camargo-Mathias MI (2010) Azadirachta indica A. Juss (neem) induced morphological changes on oocytes of Rhipicephalus sanguineus (Latreille, 1806) (Acari: Ixodidae) tick females. Exp Parasitol 126(4): 462-470.

40. Mukherjee S, Garg S, Talwar GP (1999) Early post implantation contraceptive effects of a purified fraction of neem (Azadirachta indica) seeds, given orally in rats: possible mechanisms involved. J Ethnopharmacol 67(3): 287-296.

41. Selvamurthy W (1997) Herbal contraceptive in the works. Science 278(5341): 1233.

42. Upadhyay SN, Dhawan S, Sharma MG, Talwar GP (1994) Long-term contraceptive effects of intrauterine neem treatment (IUNT) in bonnet monkeys: an alternate to intrauterine contraceptive devices (IUCD). Contraception 49(2): 161-169.

43. Ravichandran V, Arunachalam G, Subramanian N, Suresh B (2009) Contraception and its significance in traditional system of medicines. Int J Pharma Sci 1: 1-21. 
44. Dhaliwal PK, Roop JK, Guraya SS (1999) Effect of neem-seed oil on the quantitative aspects of follicular development in cyclic female rats. Indian J Ecol 26: 162-166.

45. Roop JK, Dhaliwal PK, Guraya SS (2005) Extracts of Azadirachta indica and Melia azedarach seeds inhibit follicullogenesis in albino rats. Braz J Med Biol Res 38:943-947.
46. Garg S, Taluja V, Talwar GP, Upadhyay SN (1998) Immunocontraceptive activity guided fractionation and characterization of active constituents of neem (Azadirachta indica) seed extracts. J Ethnopharmacol 60(3): 235-246.

47. Sharma SK, SaiRam M, Ilavazhagan G, Devendra K, Shiavaji SS, et al. (1996) Mechanism of action of NIM-76: a novel vaginal contraceptive from neem oil. Contraception 54(6): 373-378.

\section{Your next submission with Juniper Publishers will reach you the below assets}

- Quality Editorial service

- Swift Peer Review

- Reprints availability

- E-prints Service

- Manuscript Podcast for convenient understanding

- Global attainment for your research

- Manuscript accessibility in different formats

( Pdf, E-pub, Full Text, Audio)

- Unceasing customer service

Track the below URL for one-step submission https://juniperpublishers.com/online-submission.php 